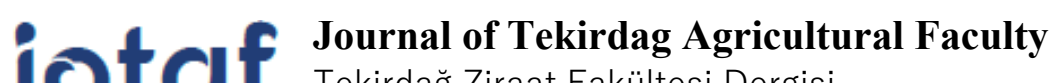 \\ Tekirdağ Ziraat Fakültesi Dergisi
}

\section{Long-term Water Productivity of Maize (Zea mays L.) From Limited Irrigation Conditions under Moderate Semi-arid Environment}

\begin{abstract}
Abolfazl NASSERI
Abstract

Crop production has a correlation with the applied water in moderate semi-arid conditions. Due to temperature and rainfall changes enhancing water productivity in crop production are needed for a limited resource conditions. In this study, maize (Zea mays L.) yields measured in fields during 11 years from 2005-2006 to 2015-2016 were compared with those simulated by the Agro-ecological Zone method under moderate semi-arid environment located at the north west of Iran with a soil texture of loamy-clay. Different research scenarios involving actual evapotranspirationc $(\mathrm{ETa})$ to potential $(\mathrm{ETm})$ value $(\mathrm{ETa} / \mathrm{ETm}=100 \%, 90 \%, 80 \%, 70 \%, 60 \%, 50 \%$ and $40 \%)$ under different water application efficiencies (Ea) of $40 \%, 50 \%, 60 \%, 70 \%, 80 \%, 90 \%$ and $100 \%$ were considered in the present study. Research scenarios affected yield and water productivity of maize. To produce potential yield of maize of $10084 \mathrm{~kg} \mathrm{ha}^{-1}$ under water application efficiency of 100, 90, 80, 70, 60, 50 and 40\%, irrigation water requirements were respectively 4683, 5203, 5854, 6690, 7805, 9366, $11708 \mathrm{~m}^{3} \mathrm{ha}^{-1}$ and water productivity were respectively $2.15,1.94,1.72,1.51,1.29,1.08,0.86 \mathrm{~kg} \mathrm{~m}^{-3}$. Results confirmed that water productivity of maize was from 1.22 to $1.52 \mathrm{~kg} \mathrm{~m}^{-3}$ with an average of $1.38 \mathrm{~kg} \mathrm{~m}^{-3}$ during 11 years under water application efficiency of $68 \%$. Because measured yield ranged from 3800 to $6971 \mathrm{~kg} \mathrm{ha}^{-1}$ with an average of $5345 \mathrm{~kg} \mathrm{ha}^{-1}$ and water applied was from 3125 to 4584 and averaged $3836 \mathrm{~m}^{3} \mathrm{ha}^{-1}$. It is suggested that limited irrigation could be applied to enhance water productivity in maize production under such moderate semi-arid environment.
\end{abstract}

Keywords: Deficit irrigation, Maize irrigation, Water application efficiency, Water productivity.

\footnotetext{
*Sorumlu Yazar/Corresponding Author: Abolfazl Nasseri, Agricultural Engineering Research Department, East Azarbaijan Agricultural and Natural Resources Research and Education Center, AREEO, Tabriz, Iran. E-mail: nasseri ab@yahoo.com (D) OrcID: 0000-0002-6758-4050. Atıf/Citation: Nasseri A. Long-term Water Productivity of Maize (Zea mays L.) from Limited Irrigation Conditions Under Moderate Semi-arid Environment. Tekirdă̆ Ziraat Fakültesi Dergisi, 18 (3), 400-410.

CBu çalışma Tekirdağ Namık Kemal Üniversitesi tarafından Creative Commons Lisansı (https://creativecommons.org/licenses/by-nc/4.0/) kapsamında yayınlanmıştır. Tekirdağ 2021
} 


\section{Introduction}

Maize (Zea mays L.) is one of the most important irrigated crop which is cultivated throughout the world and its grain is consumed by human and animal (Güneş and Fatih, 2019). Annual maize production is about 820 million ton over the world (FAO, 2011). Maize yield has positive response to sufficient irrigation water in the field. Its root system is relatively thin, it is therefore sensitive to water insufficiency stress (El-Hendawy et al., 2008). Maize irrigation scheduling depends on rate of root deepening. The rate of root deepening is $25 \mathrm{~mm}^{-} \mathrm{day}^{-}$ ${ }^{1}$ and the effective rooting of this crop reaches to $280 \mathrm{~cm}$ at the maturity time (Hsiao et al., 1976). Laboski et al. (1998) reported that about $94 \%$ of total maize root length distributed within $60 \mathrm{~cm}$ of the soil surface and about $85 \%$ of root length was within $30 \mathrm{~cm}$.

Deficit irrigation method is one of the common strategies for producing crops under water deficit and limitation conditions in the arid and semi-arid environments over of the world. Deficit irrigation efficiency in crop production is evaluated by an index known as water productivity (WP) that is crop yield from applying 1 $\mathrm{m}^{3}$ of irrigation water (Foley et al., 2020; Katerji et al., 2013). This index was considerably applied in crop irrigation researches in irrigated farms (Abadi et al., 2010; Bramley et al., 2013; Du et al., 2010; Fang et al., 2010; Guo et al., 2010; Li et al., 2010; Zhang et al., 2010; Nasseri and Bahramloo, 2009; Nasseri and Fallahi, 2007; Zamani and Nasseri, 2008). This index is defined the as the ratio of crop yield to the crop evapotranspiration or water used in crop production (Nasseri and Fallahi, 2007; Ezenne et al., 2019; Foley et al., 2020). According to the report of Hamdy et al. (2003), increasing WP is an essential priorities in the agricultural production systems under both conditions of irrigated and rainfed production systems. Davis and Hagood (1961) found that the highest water productivity in maize production were attained with an actual evapotranspiration (ETa) lower than the potential rate (ETp) and, the highest water productivity was consequently obtained at $90 \%$ of the potential yield (Yp). Foley et al. (2020) reported that enhancing crop yield without application of more water, and/or decreasing irrigation water with sustaining yields are methods to improve water productivity.

Crop yield has a significant correlation with actual evapotranspiration (ETa) and consequently irrigation water. The relation between crop production and irrigation water known as water production function. While, relation between crop production and actual evapotranspiration known as crop water production function (Kipkorir et al., 2002). Previous studies showed that maize yield is a linear function of irrigation water or seasonal evapotranspiration (Gilley et al., 1980; Payero et al., 2006; Klocke et al., 2004; Stone, 2003). According to the Kipkorir et al. (2002) in full and with non-deficit irrigation conditions, water production function in non-linear (a second or third order polynomial) indicating that some of the irrigation water was lost as deep percolation from crop root zone. While for limited irrigation condition, application of crop water production function with linear form is very advantageous and applicable which proposed by Doorenbos and Kassam (1979).

Researches confirmed that in maize production tasseling and silking stages are very sensitive to the water insufficiency stress under semi-arid conditions (Robins and Domingo, 1953; Denmead and Shaw, 1960; Musick and Dusek, 1980; Eck, 1984; Johnson et al., 1987; Rhoades and Bennett, 1990; Lamm et al., 1995). Robins and Domingo (1953) reported that soil moisture depletion to the wilting point at tassel or pollination stages of maize for a week reduced yield as $50 \%$ and for one to two days by $22 \%$. Moreover, Denmead and Shaw (1960) explained that moisture deficit stress at silking stage of maize reduced yield 50\%, whereas such stress during the vegetative stage and after silking stages decreased yields about 23\%. Musick and Dusek (1980) reported that moisture deficit stress during grain filling stage was more injurious than moisture stress during vegetative growth stage in maize production, whereas moisture deficit stress during tasseling and silking to be the most injurious. About two and four weeks of moisture deficit stress during the vegetative stage of maize reduced its yields up to 23 and 46\%, respectively (Eck, 1984). Soltanbeigi (2019) reported that the largest damage from water stress was during stages of tasseling and stalking. Also, irrigated maize responded as well to midseason irrigation as it did to more frequent irrigations at 50\% soil moisture depletion (Johnson et al., 1987). Limited irrigation strategies generally reduce maize yield according to the findings of Rhoades and Bennett (1990) and Lamm et al., (1995). In this method, crop is irrigated with available water less than potential evapotranspiration (ETp) to obtain optimum yield.

Additionally, Darusman et al. (1997) reported that drip irrigation method resulted in near-potential maize yield and reduced deep percolation losses beneath the root development zone when irrigation and rainfall was 

totally 75\% maize evapotranspiration. Moreover, Norwood (2000) reported that plant population some production inputs management systems such as irrigation and fertilizer significantly increased yields above those of dryland maize. A single irrigation at the tassel stage along with $112 \mathrm{~kg} \mathrm{~N} \mathrm{ha}^{-1}$ increased yield with an average of $29 \%$. While, two and three irrigations in combination with increased $\mathrm{N}$ rates and plant populations increased yields about $12 \%$. Note that, two irrigation events were applied at the tassel and dough stage of grain fill and three events were at the 9 to 10 leaf stage; and at tassel and dough stage of grain fill of maize production. Limited Irrigation such as every other- furrow irrigation method is one of the effective strategies to save agricultural water, while application efficiency in conventional furrow irrigation is less than every other-furrow irrigation. Research findings show that to produce a similar maize yield, furrow irrigation by every other method with interval of 4 day consumed less water than 7 day interval. In terms of economic analysis the every other method is profitable, as well (Khajeabdollahi and Sepaskhah, 1996).

Water productivity of maize was investigated by researchers over the world under different conditions of irrigation treatments, fertilizers rates and crop populations (Howell et al., 1995; Al-Kaisi and Yin, 2003; Karam et al., 2003; Payero et al., 2008; Katerji et al., 2010; El-Wahed and Ali, 2013; Katerji et al., 2013). But research of WP under unusual conditions for actual evapotranspiration in moderate semi-arid environment was not accomplished. Therefore, the main objectives of this study was to investigate the effect of different ETa/ETm on maize yield and water productivity with different water application efficiencies (Ea) of 40\% to $100 \%$ under moderate semi-arid environment; and to compare maize yields measured from fields during 11 years from 20052006 to 2015-2016 with those simulated by the Agro-ecological Zone method; and to acquire water production function for full and limited irrigation conditions.

\section{Materials and methods}

\subsection{Site description}

The present study was conducted on the farms with moderate semi-arid conditions at the north west of Iran with latitude $39^{\circ} 39^{\prime} \mathrm{N}$, longitude $47^{\circ} 55^{\prime} \mathrm{E}$ and $31.9 \mathrm{~m}$ above mean sea level. The region soil was clssified from loamy-clay with wilting point (PWP), field capacity (FC) and acidity ( $\mathrm{pH}$ ) of $16 \%, 25.4 \%$ and 7 , respectively to clay-loam with average WP, FC, and $\mathrm{pH}$ of $22.36 \%, 31.51 \%$ and 7.2 , respectively. Studied region at the north west of Iran is shown by Figure 1.

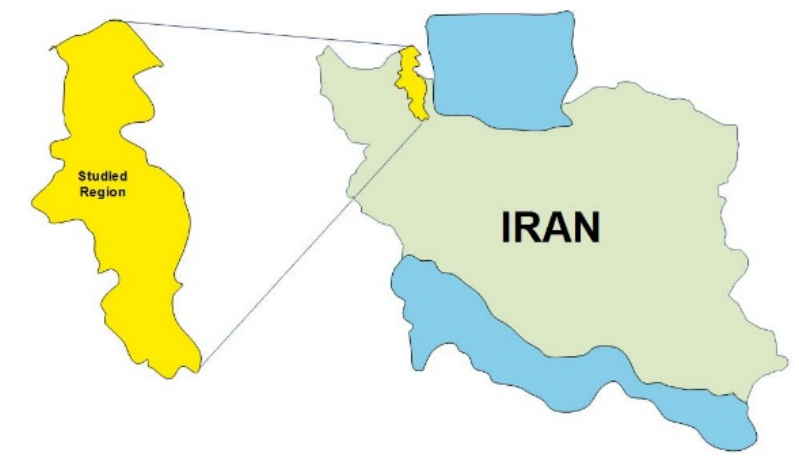
Figure 1. Studied region (Moghan plain) for evaluation of yield and water productivity of maize at the
north west of Iran.

Meteorological data such as air temperature and rainfall were obtained from meteorological station located at near of the farms with abovementioned latitude and longitude. The highest and lowest air temperature during the growing seasons of maize ranged from 10 to $30{ }^{\circ} \mathrm{C}$ and 0 to $16{ }^{\circ} \mathrm{C}$, respectively. Maize evapotranspiration (ETp) was 468 and annual rainfall $277 \mathrm{~mm}$ with effective rainfall of $50 \pm 7 \mathrm{~mm}$. Based on long-term meteorological data of vapor pressure deficit, wind function and net radiation, reference evapotranspiration (ETo in $\mathrm{mm} \mathrm{month}^{-1}$ ) was estimated with Penman's method under standard conditions for maize production. The potential evapotranspiration (ETp in $\mathrm{mm} \mathrm{month}^{-1}$ ) for maize was subsequently acquired by reference evapotranspiration and crop coefficient. Maize yields obtained from farms in the region for 11 years from 2005 2006 to 2015-2016 (Golizadeh et al., 2014). Results were compared with the simulated yields by the methods of Doorenbos and Kassam (1979). 


\subsection{Study scenarios}

Different research scenarios involving actual evapotranspiration to potential value (ETa/ETm $=100 \%, 90 \%$, $80 \%, 70 \%, 60 \%, 50 \%$ and $40 \%$ ) under different water application efficiencies (Ea) of 40\%, 50\%, 60\%, 70\%, $80 \%, 90$ and $100 \%$ were considered in the present study. The potential yield of maize was determined by the Agro-ecological Zone method (Doorenbos and Kassam, 1979). Index of water productivity (WP) from each scenario was subsequently estimated by the following relation. The potential yield of maize was determined by the Agro-ecological Zone method (Doorenbos and Kassam, 1979). Index of water productivity (WP) from each scenario was subsequently estimated by the following relation (Eq.1).

WP $\left(\mathrm{kg} \mathrm{m}^{-3}\right)=$ Maize yield $\left(\mathrm{kg} \mathrm{ha}^{-1}\right) /$ Water applied $\left(\mathrm{m}^{3} \mathrm{ha}^{-1}\right)$

\subsection{Maize yield and evapotranspiration relation}

Preceding studies showed that maize yield is a linear function of seasonal evapotranspiration (Gilley et al., 1980; Payero et al., 2006; Klocke et al., 2004; Stone, 2003). Also, the linear relationship between relative crop yield $(\mathrm{Ya} / \mathrm{Ym})$ and relative maize evapotranspiration $(\mathrm{ETa} / \mathrm{ETm})$ as the following relation developed by Doorenbos and Kassam (1979) for the first time. Recently, Süheri et al. (2020) related crop yield to the evapotranspiration (Eq.2):

$$
\left(\frac{\mathrm{Ym}-\mathrm{Ya}}{\mathrm{Ym}}\right)=\operatorname{Ky}\left(\frac{\mathrm{ETm}-\mathrm{ETa}}{\mathrm{ETm}}\right)
$$

Where $\mathrm{Ya}$ is the actual maize yield $\left(\mathrm{kg} \mathrm{ha}^{-1}\right)$ from ETa $\left(\mathrm{m}^{3}\right)$ and $\mathrm{Ym}$ is the potential maize yield $\left(\mathrm{kg} \mathrm{ha}^{-1}\right)$ from $\operatorname{ETm}\left(\mathrm{m}^{3}\right)$; and ETa and ETm are respectively actual and potential maize evapotranspiration during growing season. Moreover, Ky is crop yield response factor that depends on crop growth stage and irrigation management. Ky was $0.40,0.9,0.50,0.2$ and 1.25 for vegetative, flowering, yield formation, ripening and total growing stages in maize production (Doorenbos and Kassam, 1979). The Agro-ecological Zone method was applied to simulate maize potential yield for a Moderate semi-arid environment at the north-west of Iran (Doorenbos and Kassam, 1979). Maize variety was Single cross 704 with rooting depth of $20 \mathrm{~cm}$ (week 0-4) and $80 \mathrm{~cm}$ (week 9-20) which seed planting and end dates were from 1 April to 30 July. Yield was harvest at maturity stage when seed moisture was 11- 13\%. Maize farms were irrigated by furrow irrigation system with intervals of 7 days and water application efficiency of $68 \%$ (Abbasi et al., 2016).

\subsection{Estimation of seasonal potential evapotranspiration (ETm)}

The seasonal potential evapotranspiration (ETm in $\mathrm{mm}$ ) of maize was estimated based on the reference evapotranspiration (ETo in $\mathrm{mm}$ ) and crop coefficient $(\mathrm{Kc})$ by the following relation (Doorenbos and Kassam, 1979) (Eq.3):

$\mathrm{ETm}=\mathrm{Kc} \times \mathrm{ETo}$

Crop coefficient $(\mathrm{Kc})$ for maize development stages was 0.35-0.70 (day 0-60), 0.71-1.05 (day 61-90), 1.050.60 (day 91-120) at studied region. The reference evapotranspiration (ETo in $\mathrm{mm}$ ) was estimated by the Penman's method (Penman, 1950; Penman, 1953) (Eq.4):

$$
\mathrm{ETo}=\mathrm{C} \times(\mathrm{W} \times \mathrm{Rn}+(1-\mathrm{W}) \times \mathrm{F}(\mathrm{u}) \times(\text { ea-ed }))
$$

where $\mathrm{ETo}=$ the reference evapotranspiration in $\mathrm{mm} \mathrm{day}^{-1}$; (ea-ed) $=$ vapor pressure deficit i.e. the difference between saturation vapor pressure (ea) at mean air temperature (in mbar) and actual vapor pressure (ed) in mbar where can be estimated by ed $=\mathrm{ea} \times \mathrm{RH} / 100 ; \mathrm{F}(\mathrm{u})=$ wind function; $\mathrm{Rn}=$ total net radiation in $\mathrm{mm} \mathrm{day}^{-1}$ and $\mathrm{C}=$ adjustment factor .

\subsection{Estimation of potential yield of maize}

Potential yield (Ymp) of maize was estimated by the following relation known as the Agro-ecological Zone method (Doorenbos and Kassam, 1979) (Eq.5): 
where $\mathrm{CL}=$ correction for crop development and leaf area, 0.50 for maize; $\mathrm{CN}=$ correction for dry matter production, 0.50 for maize; $\mathrm{CH}=$ correction for harvested index, 0.40 for maize; $\mathrm{G}=$ total growing period (days) which was 150 days at the studied region; Yo = gross dry matter production of standard crop was calculated as (Eq.6):

$$
\mathrm{Yo}=\mathrm{F} \times(0.8+0.01 \times \mathrm{Ym}) \times \mathrm{Yo}+(1-\mathrm{F}) \times(0.5+0.025 \times \mathrm{Ym}) \times \mathrm{Yc}
$$

where $\mathrm{Yo}_{\mathrm{o}}=$ gross dry matter production of standard crop $\left(\mathrm{kg} \mathrm{ha}^{-1}\right.$ day $\left.^{-1}\right) ; \mathrm{F}=$ fraction of the daytime that sky is clouded which was obtained as 0.30 for the studied region and can be obtained from (Eq.7):

$$
\mathrm{F}=(\text { Rse- } 0.5 \times \mathrm{Rs}) /(0.8 \times \text { Rse })
$$

in which Rse $=$ the maximum active in coming shortwave radiation on clear days in cal $\mathrm{cm}^{-2} \mathrm{day}^{-1}$; Rs $=$ the actual measured incoming shortwave radiation in cal $\mathrm{cm}^{-2} \mathrm{day}^{-1} ; \mathrm{Yo}=$ gross dry matter production rate of standard crop for a given location on a completely overcast day $\left(\mathrm{kg} \mathrm{ha}^{-1}\right.$ day $\left.^{-1}\right)$; Yc $=$ gross dry matter production rate of standard crop for a given location on a clear (cloudless) in $\mathrm{kg} \mathrm{ha}^{-1}$ day $^{-1}$; Ym = maximum leaf gross dry matter production rate of a crop for a given climate $\left(\mathrm{kg} \mathrm{ha}^{-1} \mathrm{day}^{-1}\right)$.

\section{Results and Discussion}

In Figure 2 crop coefficient and monthly and cumulative potential evapotranspiration of maize during days after seed sowing were depicted. Results showed that crop coefficient for maize varied from 0.35 (0-30 days after seed sowing) to 1.05 (61-90 days after seed sowing). The highest potential evapotranspiration was obtained $193 \mathrm{~mm} \mathrm{month}^{-1}$ (61-90 days after seed sowing) and cumulative potential evapotranspiration during growing season under mmoderate semi-arid conditions was $468 \mathrm{~mm}$. Also, application of Agro-ecological Zone method produced the potential yield (Ym) of maize as $10084 \mathrm{~kg} \mathrm{ha}^{-1}$ with net water for irrigation of $4680 \mathrm{~m}^{3} \mathrm{ha}^{-1}$.

Previous studies demonstrated that maize yield is a linear function of water requirement (Gilley et al., 1980; Payero et al., 2006; Klocke et al., 2004; Stone, 2003). Therefore, in the present study similar to the findings of previous researches, maize yield increased with increasing irrigation water application on the farms and linear water-production function for maize was consequently acquired by plotting irrigation water ( $\mathrm{mm}$ ) on the $\mathrm{X}$-axis and maize yield $\left(\mathrm{kg} \mathrm{ha}^{-1}\right)$ on the $\mathrm{Y}$-axis which is illustrated in Figure 2 and 3 for furrow irrigation with application efficiency from $100 \%$ to $40 \%$. Effective rainfall during maize growing season was not considered in the functions. The best fitting function for water-yield relations were as following Table 1.
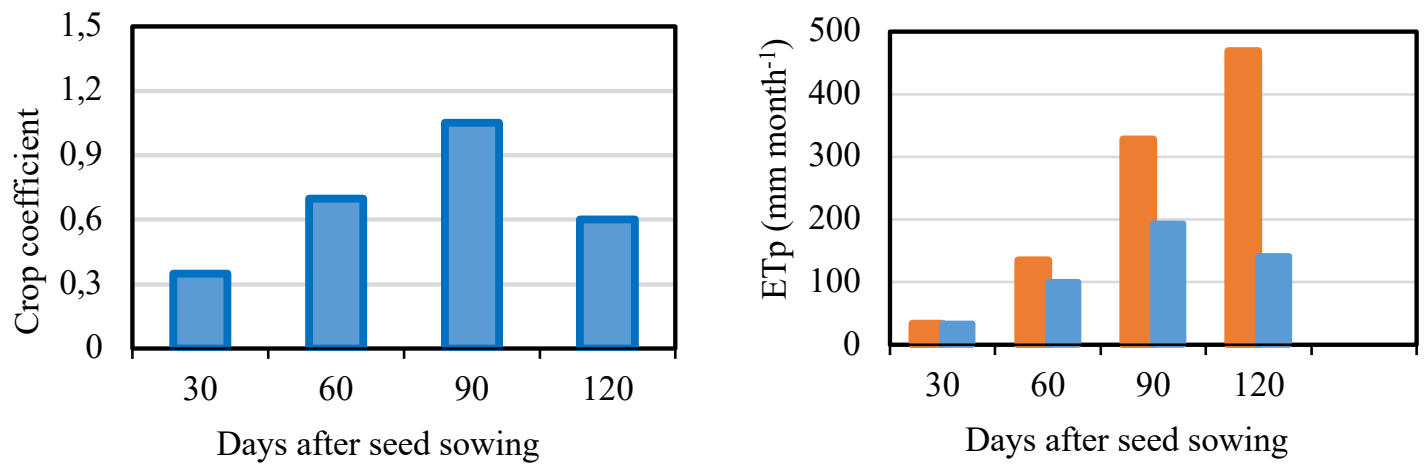

Figure 2. Crop coefficient, monthly and cumulative evapotranspiration of maize during days after seed sowing 


\begin{tabular}{|c|c|c|c|}
\hline \multirow[t]{2}{*}{ Water application efficiency (\%) } & \multicolumn{2}{|c|}{ Yield $\left(\mathrm{kg} \mathrm{ha}^{-1}\right)=\mathrm{a}($ Water applied in $\mathrm{mm})-\mathrm{b}$} & \multirow[t]{2}{*}{$\mathbf{R}^{2}$} \\
\hline & $\mathbf{a}$ & b & \\
\hline $\mathbf{E a}=100 \%$ & 26.917 & 2521 & 0.99 \\
\hline $\mathbf{E a}=\mathbf{9 0} \%$ & 24.225 & 2521 & 0.99 \\
\hline $\mathbf{E a}=\mathbf{8 0} \%$ & 21.533 & 2521 & 0.99 \\
\hline $\mathbf{E a}=70 \%$ & 18.842 & 2521 & 0.99 \\
\hline $\mathbf{E a}=60 \%$ & 16.150 & 2521 & 0.99 \\
\hline $\mathbf{E a}=\mathbf{5 0 \%}$ & 13.458 & 2521 & 0.99 \\
\hline $\mathrm{Ea}=\mathbf{4 0} \%$ & 10.767 & 2521 & 0.99 \\
\hline
\end{tabular}

To produce potential yield of maize of $10084 \mathrm{~kg} \mathrm{ha}^{-1}$ under water application efficiency of 100, 90, 80, 70, 60, 50 and 40\%, irrigation water requirement was respectively 4683, 5203, 5854, 6690, 7805, 9366, $11708 \mathrm{~m}^{3}$ $\mathrm{ha}^{-1}$. Therefore, with increasing water application efficiency, irrigation water requirement to produce potential yield was obviously decreased. Consequently, to achieve potential yield, water productivity were respectively $2.15,1.94,1.72,1.51,1.29,1.08,0.86 \mathrm{~kg} \mathrm{~m}^{-3}$ under water application efficiency of 100, 90, 80, 70, 60, 50 and $40 \%$ (Figs. 3 and 4). Under actual evaporanspiration as $90 \%$ potential ones $(\mathrm{Eta} / \mathrm{ETm}=0.90)$ in order to produce $88 \%$ of potential yield of maize $\left(\mathrm{Ya} / \mathrm{Ym}=0.88\right.$ and $\left.\mathrm{Ya}=8824 \mathrm{~kg} \mathrm{ha}^{-1}\right)$, irrigation water requirement (and water productivity) is $10537\left(0.84 \mathrm{~kg} \mathrm{~m}^{-3}\right), 8429\left(1.05 \mathrm{~kg} \mathrm{~m}^{-3}\right), 7025\left(1.26 \mathrm{~kg} \mathrm{~m}^{-3}\right), 6021\left(1.47 \mathrm{~kg} \mathrm{~m}^{-3}\right), 5268(1.67 \mathrm{~kg}$ $\left.\mathrm{m}^{-3}\right), 4683\left(1.88 \mathrm{~kg} \mathrm{~m}^{-3}\right), 4215\left(2.09 \mathrm{~kg} \mathrm{~m}^{-3}\right) \mathrm{m}^{3} \mathrm{ha}^{-1}$ under water application efficiency of 40, 50, 60, 70, 80, 90 and $100 \%$, respectively (Figs. 3 and 4 ). Under actual evaporanspiration as $80 \%$ potential ones $(\mathrm{Eta} / \mathrm{ETm}=0.80)$ in order to produce $75 \%$ of potential yield $\left(\mathrm{Ya} / \mathrm{Ym}=0.75\right.$ and $\left.\mathrm{Ya}=7563 \mathrm{~kg} \mathrm{ha}^{-1}\right)$ of maize, irrigation water requirement (and water productivity) is $3746\left(2.02 \mathrm{~kg} \mathrm{~m}^{-3}\right), 4163\left(1.82 \mathrm{~kg} \mathrm{~m}^{-3}\right), 4683\left(1.61 \mathrm{~kg} \mathrm{~m}^{-3}\right), 535.2(1.41$ $\left.\mathrm{kg} \mathrm{m}^{-3}\right), 6244\left(1.21 \mathrm{~kg} \mathrm{~m}^{-3}\right), 7493\left(1.01 \mathrm{~kg} \mathrm{~m}^{-3}\right), 9366\left(0.81 \mathrm{~kg} \mathrm{~m}^{-3}\right) \mathrm{m}^{3} \mathrm{ha}^{-1}$ under water application efficiency of 100, 90, 80, 70, 60, 50 and 40\%, respectively (Figs. 3 and 4).

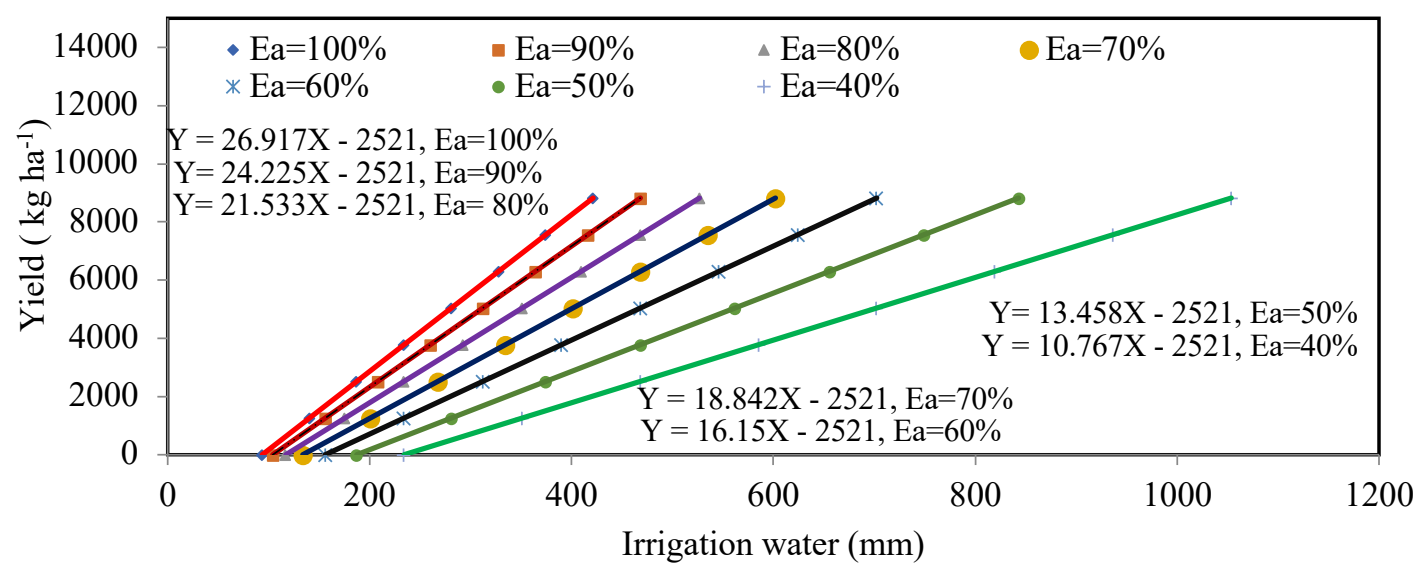

Figure 3. Crop yield versus irrigation water under moderate semi-arid conditions

Under actual evaporanspiration as $70 \%$ potential ones $(\mathrm{Eta} / \mathrm{ETm}=0.70)$ in order to produce $63 \%$ of potential yield $\left(\mathrm{Ya} / \mathrm{Ym}=0.63\right.$ and $\left.\mathrm{Ya}=6302 \mathrm{~kg} \mathrm{ha}^{-1}\right)$ of maize, irrigation water requirement (and water productivity) is $3278\left(1.92 \mathrm{~kg} \mathrm{~m}^{-3}\right), 3642\left(1.73 \mathrm{~kg} \mathrm{~m}^{-3}\right), 4098\left(1.54 \mathrm{~kg} \mathrm{~m}^{-3}\right), 4683\left(1.35 \mathrm{~kg} \mathrm{~m}^{-3}\right), 5464\left(1.15 \mathrm{~kg} \mathrm{~m}^{-3}\right), 6556(0.96$ $\left.\mathrm{kg} \mathrm{m}^{-3}\right), 8195\left(0.77 \mathrm{~kg} \mathrm{~m}^{-3}\right) \mathrm{m}^{3} \mathrm{ha}^{-1}$ under water application efficiency of 100, 90, 80, 70, 60, 50 and $40 \%$, respectively (Figs. 3 and 4). Under actual evaporanspiration as $60 \%$ potential ones $(\mathrm{Eta} / \mathrm{ETm}=0.60)$ in order to produce $50 \%$ of potential yield $\left(\mathrm{Ya} / \mathrm{Ym}=0.50\right.$ and $\left.\mathrm{Ya}=5042 \mathrm{~kg} \mathrm{ha}^{-1}\right)$ of maize, irrigation water requirement (and water productivity) is $7025\left(0.72 \mathrm{~kg} \mathrm{~m}^{-3}\right), 5620\left(0.90 \mathrm{~kg} \mathrm{~m}^{-3}\right), 4683\left(1.08 \mathrm{~kg} \mathrm{~m}^{-3}\right), 4014\left(1.26 \mathrm{~kg} \mathrm{~m}^{-3}\right), 3512(1.44$ $\left.\mathrm{kg} \mathrm{m}^{-3}\right), 3122\left(1.61 \mathrm{~kg} \mathrm{~m}^{-3}\right), 2810\left(1.79 \mathrm{~kg} \mathrm{~m}^{-3}\right) \mathrm{m}^{3} \mathrm{ha}^{-1}$ under water application efficiency of 40, 50, 60, 70, 80, 90 and $100 \%$, respectively (Figs. 3 and 4). Under actual evaporanspiration as 50\% potential ones (Eta/ETm=0.50) in order to produce $38 \%$ of potential yield $\left(\mathrm{Ya} / \mathrm{Ym}=0.38\right.$ and $\left.\mathrm{Ya}=3782 \mathrm{~kg} \mathrm{ha}^{-1}\right)$ of maize, irrigation water requirement (and water productivity) was $2342 \mathrm{~m}^{3} \mathrm{ha}^{-1}\left(1.61 \mathrm{~kg} \mathrm{~m}^{-3}\right)$ under water application efficiency of $100 \%$. Also, irrigation water requirement (and water productivity) was $2602\left(1.45 \mathrm{~kg} \mathrm{~m}^{-3}\right)$ under water application 
Long-term Water Productivity of Maize (Zea mays L.) From Limited Irrigation Conditions Under Moderate Semi-arid Environment efficiency of $90 \%$. Moreover, irrigation water requirement (and water productivity) was $2927\left(1.29 \mathrm{~kg} \mathrm{~m}^{-3}\right) \mathrm{under}^{2}$ water application efficiency of $80 \%$. With water application efficiency of $70 \%$, irrigation water requirement and water productivity were 3345 and $1.13 \mathrm{~kg} \mathrm{~m}^{-3}$, repectively. Moreover, irrigation water requirement was 3903, 4683 and $5854 \mathrm{~m}^{3}$ under water application efficiency of $60 \%, 50 \%$ and $40 \%$, respectively. Under these application efficiency, water productivity was $0.97,0.81$ and $0.65 \mathrm{~kg} \mathrm{~m}^{-3}$, respectively (Figs. 3 and 4).

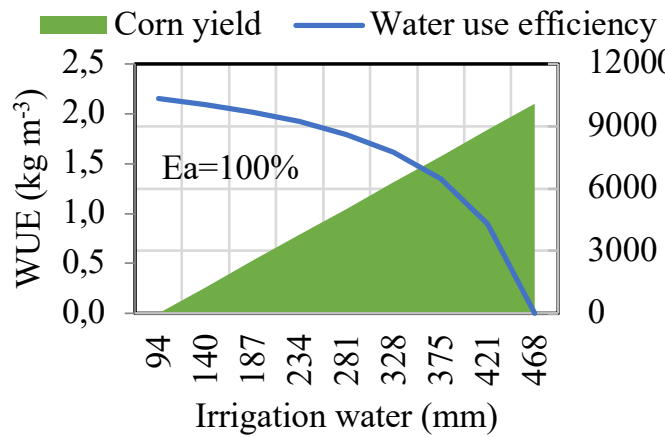

Irrigation water $(\mathrm{mm})$

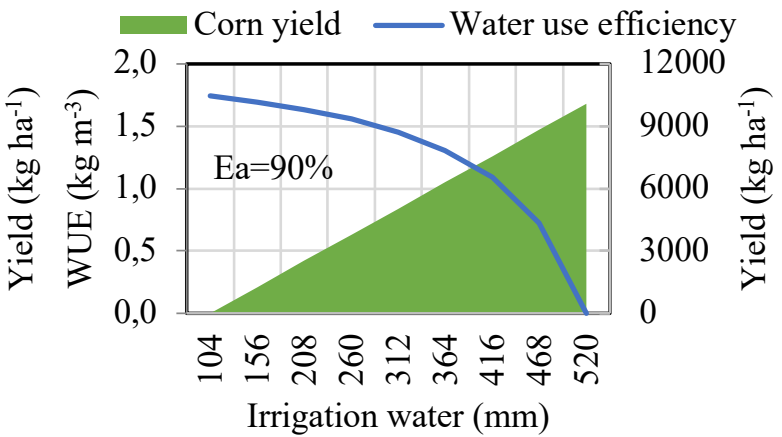

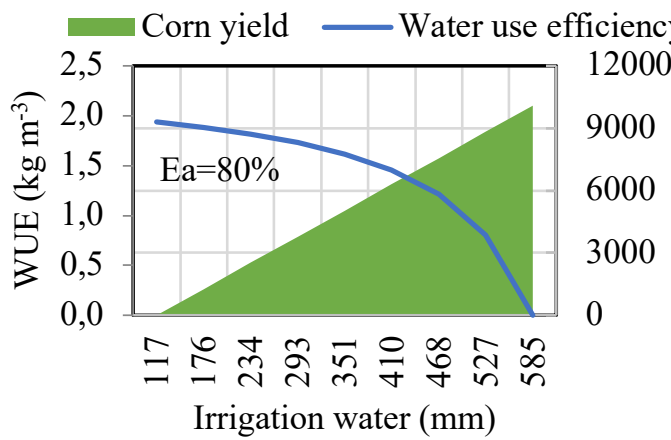
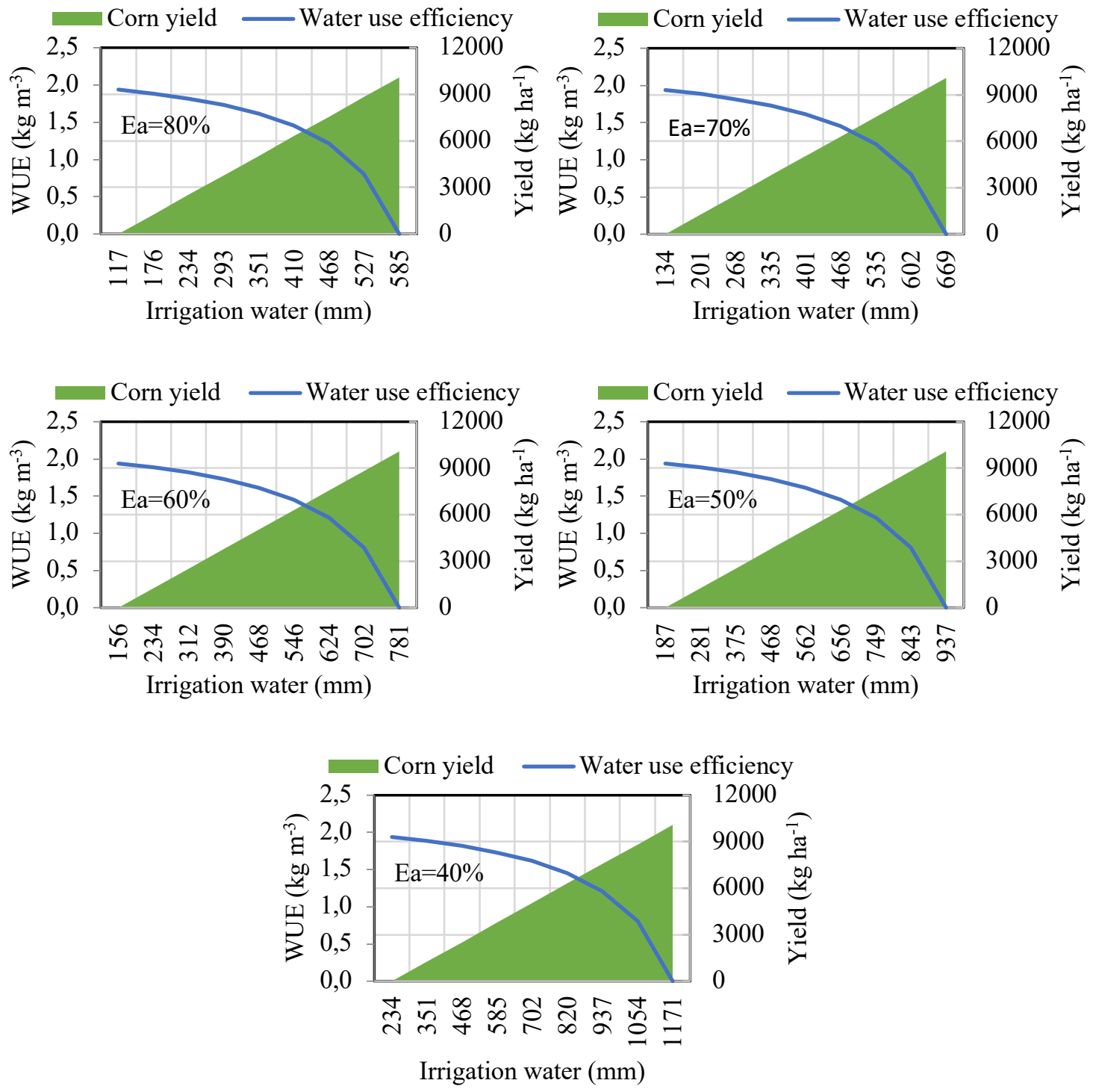

Figure 4. Maize yield and water productivity from irrigation water application under moderate semi-arid conditions 
Measured yield, water applied and water productivity of maize during 11 years from 2005-2006 to 20152016 under actual and conventional conditions were presented in Figs 5 and 6 . Results confirmed that measured yield during 11 years ranged from 3800 (in 2007-2008) to $6971 \mathrm{~kg} \mathrm{ha}^{-1}$ (in 2015-2016) with an averge of 5345 $\mathrm{kg} \mathrm{ha}^{-1}$. Note that, water applied to produce maize was from 3125 to 4584 and averaged $3836 \mathrm{~m}^{3} \mathrm{ha}^{-1}$ (Fiure 5). Simliar to the findings of researchers (Abadi et al., 2010; Bramley et al., 2013; Du et al., 2010; Fang et al., 2010; Guo et al., 2010; Li. 2010; Zhang et al., 2010; Nasseri and Bahramloo, 2009; Nasseri and Fallahi, 2007; Zamani and Nasseri, 2008), index of water productivity was applied to evaluate water use of maize in seed production. Water productivity was from 1.22 to $1.52 \mathrm{~kg} \mathrm{~m}^{-3}$ with an average of $1.38 \mathrm{~kg} \mathrm{~m}^{-3}$ (Figure 6) during 11 years. Water aplication efficiency was $68 \%$ in maize farms (Abbasi et al., 2016). It is recommend that limited irrigation could be applied to enhence water productivity in maize production under studied environment. Further studies are necessary to evaluate interaction effect of limited irrigation and fertilizers viz. NPK applications on maize yield under moderate semi-arid environment.

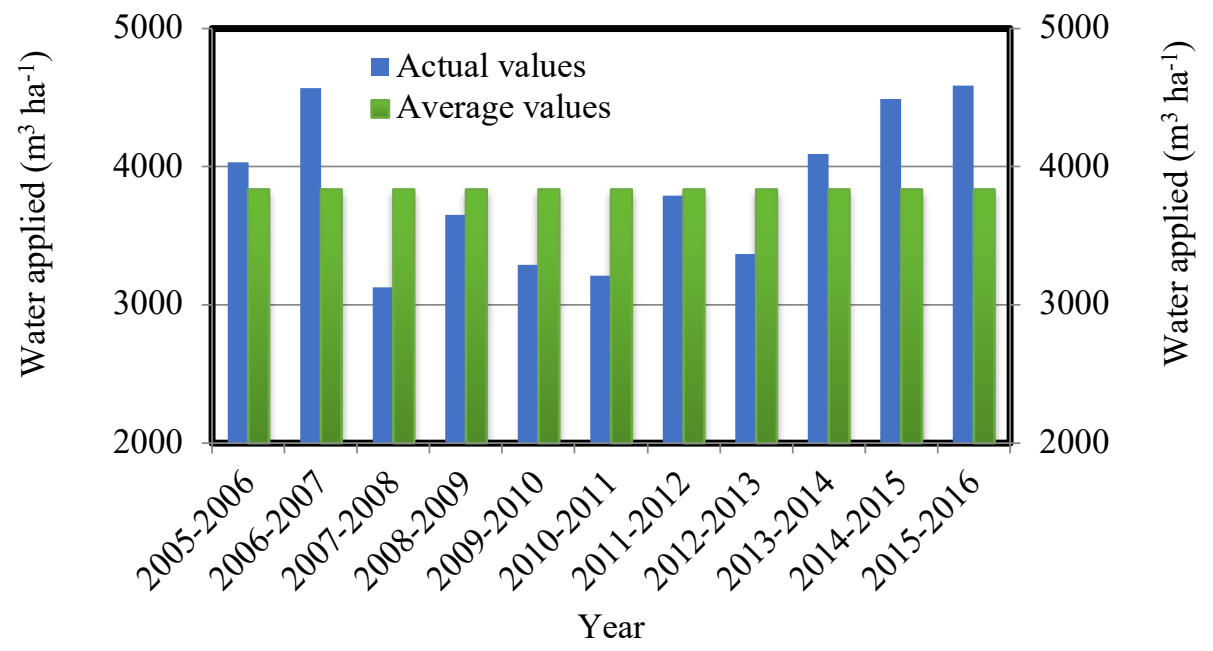

Figure 5. Measured maize yield and irrigation water during 11 years from 2005-2006 to 2015-2016

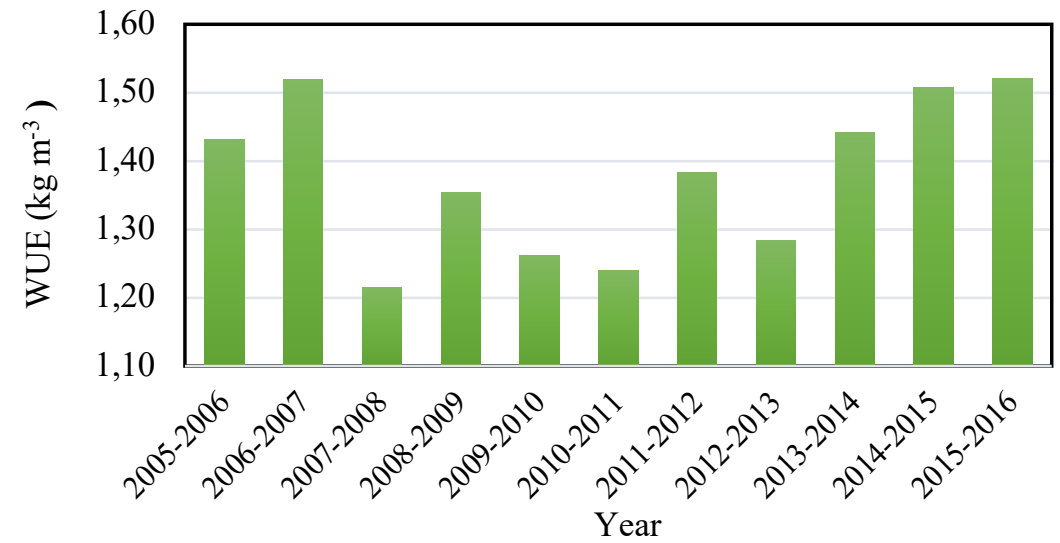

Figure 6. Water productivity of maize during 11 years from 2005-2006 to 2015-2016

\section{Conclusion}

Maize (Zea mays L.) yields measured in fields during 11 years from 2005-2006 to 2015-2016 were compared with those simulated by the Agro-ecological Zone method under moderate semi-arid environment in this study. Research scenarios comprising ETa/ETm under different water application efficiencies affected yield and water productivity of maize. The best water-production function was acquired to estimate or forecast maize yield with available water for irrigation. Index of water productivity of maize was from 1.22 to $1.52 \mathrm{~kg} \mathrm{~m}^{-3}$ with an average of $1.38 \mathrm{~kg} \mathrm{~m}^{-3}$ during 11 years under water aplication efficiency of $68 \%$. Because measured yield ranged from 
Long-term Water Productivity of Maize (Zea mays L.) From Limited Irrigation Conditions Under Moderate Semi-arid Environment 3800 to $6971 \mathrm{~kg} \mathrm{ha}^{-1}$ with an averge of $5345 \mathrm{~kg} \mathrm{ha}^{-1}$ and water applied was from 3125 to 4584 and averaged 3836 $\mathrm{m}^{3} \mathrm{ha}^{-1}$. It is proposed that limited irrigation could be employed to enhence water productivity in maize production under moderate semi-arid environment. Further studies is essential to evaluate interaction effect of limited irrigation and fertilizers (NPK) applications on maize production under such moderate semi-arid environment. 


\section{References}

Abadi, A. G. F., Nasseri, A., and Nosrati, A. E. (2010). Water use efficiency and yield of garlic responses to the irrigation system, intra-row spacing and nitrogen fertilization. Journal of Food, Agriculture and Environment, 8(2), 344-346.

Abbasi, F., F. Sohrab and N. Abbasi, (2016). Evaluating on irrigation efficiencies and temporal and spatial variations in Iran. Technical Report No. 48496, Agricultural Engineering Research Institute.

Al-Kaisi, M. M., and Yin, X. (2003). Effects of nitrogen rate, irrigation rate, and plant population on corn yield and water use efficiency. Agronomy journal, 95(6), 1475-1482.

Bramley, H., Turner, N. C., and Siddique, K. H. (2013). Water use efficiency. In Genomics and breeding for climate-resilient crops (pp. 225268). Springer, Berlin, Heidelberg.

Darusman A.H., Khan L.R., Stone W.E., Spurgeon, Lamm F.R. (1997). Water flux below the root zone vs. irrigation amount in drip-irrigated corn. Agron. J. 89, 375-379.

Davis, J. R. and M. A. Hagood. (1961). Efficient distribution of water in irrigating annual crops with limited supplies in drought years. California Agriculture. 15, 6-8.

Denmead O.T., Shaw R.H. (1960). The effects of soil moisture stress at different stages of growth on the development and yield of corn. Agron J. 52,272-274.

Doorenbos, J., and Kassam, A. H. (1979). Yield response to water. Irrigation and drainage paper, 33, 257.

Du, T., Kang, S., Sun, J., Zhang, X., and Zhang, J. (2010). An improved water use efficiency of cereals under temporal and spatial deficit irrigation in north China. Agricultural Water Management, 97(1), 66-74.

Eck H.V. (1984). Irrigated corn yield response to nitrogen and water. Agron. J.; 76:421-428.

El-Hendawy, S. E., El-Lattief, E. A. A., Ahmed, M. S., and Schmidhalter, U. (2008). Irrigation rate and plant density effects on yield and water use efficiency of drip-irrigated corn. Agricultural Water Management, 95(7), 836-844.

El-Wahed, M. A., and Ali, E. A. (2013). Effect of irrigation systems, amounts of irrigation water and mulching on corn yield, water use efficiency and net profit. Agricultural Water Management, 120, 64-71.

Ezenne, G. I., Jupp, L., Mantel, S. K., and Tanner, J. L. (2019). Current and potential capabilities of UAS for crop water productivity in precision agriculture. Agricultural Water Management, 218, 158-164.

FAO. 2011. FAOSTAT online database, available at link http://faostat.fao.org/.accessed on December 2011.

Fang, Q., Ma, L., Yu, Q., Ahuja, L. R., Malone, R. W., and Hoogenboom, G. (2010). Irrigation strategies to improve the water use efficiency of wheat-maize double cropping systems in North China Plain. Agricultural Water Management, 97(8), 1165-1174.

Foley, D. J., Thenkabail, P. S., Aneece, I. P., Teluguntla, P. G., \& Oliphant, A. J. (2020). A meta-analysis of global crop water productivity of three leading world crops (wheat, corn, and rice) in the irrigated areas over three decades. International Journal of Digital Earth, 13(8), 939-975.Gilley, J.R., Watts, D.G., Sullivan, C.Y., 1980. Management of irrigation agriculture with a limited water and energy supply. Institute of Agriculture and Natural Resources, University of Nebraska-Lincoln, 168 pp.

Golizadeh, H., Ebadzadeh, H.R., Hatami, F., Hosseinpour, R., Mohiti, Z., Fazli, M., Rezaei, M.M., Arab, H., Kazemifard, R., Fazli, B., Abdshah, H., Sefidi, H., Rafiei, M., Kazemian, A., (2014). Crop production features (2012-2013) in Iran. Agricultural Ministry. Islamic Republic of Iran, pp. 167 (in Farsi).

Güneş, A., and Fatih, Ö. N. E. R. (2019). Determination of Silage Yield and Quality Characteristics of Some Maize (Zea mays L.) Varieties. Journal of Tekırdag Agricultural Faculty, 16(1), 42-50.

Guo, R., Lin, Z., Mo, X., and Yang, C. (2010). Responses of crop yield and water use efficiency to climate change in the North China Plain. Agricultural Water Management, 97(8), 1185-1194.

Hamdy, A., Ragab, R., and Scarascia-Mugnozza, E. (2003). Coping with water scarcity: water saving and increasing water productivity. Irrigation and drainage, 52(1), 3-20.

Hsiao, T. C., Fereres, E., Acevedo, E., and Henderson, D. W. (1976). Water stress and dynamics of growth and yield of crop plants. In Water and plant life (pp. 281-305). Springer, Berlin, Heidelberg.

Howell, T. A., Yazar, A., Schneider, A. D., Dusek, D. A., and Copeland, K. S. (1995). Yield and water use efficiency of corn in response to LEPA irrigation. Transactions of the ASAE, 38(6), 1737-1747.

Johnson, B.S., Blake G.R., Nelson W.W. (1987). Midseason soil water recharge for corn in the Northwestern Corn Belt. Agron. J. 79:661667.

Karam, F., Breidy, J., Stephan, C., and Rouphael, J. (2003). Evapotranspiration, yield and water use efficiency of drip irrigated corn in the Bekaa Valley of Lebanon. Agricultural Water Management, 63(2), 125-137. 
Long-term Water Productivity of Maize (Zea mays L.) From Limited Irrigation Conditions Under Moderate Semi-arid Environment Katerji, N., Campi, P., and Mastrorilli, M. (2013). Productivity, evapotranspiration, and water use efficiency of corn and tomato crops simulated by AquaCrop under contrasting water stress conditions in the Mediterranean region. Agricultural Water Management, 130, 14-26.

Katerji, N., Mastrorilli, M., and Cherni, H. E. (2010). Effects of corn deficit irrigation and soil properties on water use efficiency. A 25-year analysis of a Mediterranean environment using the STICS model. European Journal of Agronomy, 32(2), $177-185$.

Kipkorir, E.C., Raes, D. and Massawe, B. (2002). Seasonal water production functions and yield response factors for maize and onion in Perkerra, Kenya. Agricultural Water Management, 56(2), 229-240.

Klocke, N.L., Schneekloth, J.P., Melvin, S., Clark, R.T., Payero, J.O., (2004). Field scale limited irrigation scenarios for water policy strategies. Appl. Eng. Agric. 20,623-631.

Laboski, C. A. M., Dowdy, R. H., Allmaras, R. R., and Lamb, J. A. (1998). Soil strength and water content influences on corn root distribution in a sandy soil. Plant and Soil, 203(2), 239-247.

Lamm, F. R., Manges, H. L., Stone, L. R., Khan, A. H., and Rogers, D. H. (1995). Water requirement of subsurface drip-irrigated corn in northwest Kansas. Transactions of the ASAE, 38(2), 441-448.

Li, Q., Dong, B., Qiao, Y., Liu, M., and Zhang, J. (2010). Root growth, available soil water, and water-use efficiency of winter wheat under different irrigation regimes applied at different growth stages in North China. Agricultural Water Management, 97(10), 1676-1682.

Musick J.T., Dusek D.A. (1980). Irrigated corn yield response to water. Trans. Am. Soc. Agric. Eng. 23:92-98

Nasseri, A. (1999). Analysis and Optimization of Water Use-Crop Yield Relations in Moghan. 9th Seminar of Iranian National Comittee on Irrigation and Drainage.

Nasseri, A. (2005). Yield function of corn in the regions of Iran. National meeting on corn. Khozestan Agricultural Organization. Iran.

Nasseri, A. (2006). Water Use Effects on Corn Production in Moghan, Tabriz and Khoy (Iran). 7th Meeting of Islamic Azad University on Agriculture and Natural Resources, Tabriz, Iran.

Nasseri, A., and Bahramloo, R. (2009). Potato cultivar Marfuna yield and water use efficiency responses to early-season water stress. Int. J. Agric. Biol, 11, 201-204.

Nasseri, A., and Fallahi, H. A. (2007). Water use efficiency of winter wheat under deficit irrigation. Journal of Biological sciences, 7(1), 2128.

Norwood, C. A, (2000). Water use and yield of limited-irrigated and dryland corn. Soil Science Society of America Journal, 64,365-370.

Payero, J. O., Tarkalson, D. D., Irmak, S., Davison, D., and Petersen, J. L. (2008). Effect of irrigation amounts applied with subsurface drip irrigation on corn evapotranspiration, yield, water use efficiency, and dry matter production in a semiarid climate. Agricultural Water Management, 95(8), 895-908.

Payero, J.O., Melvin, S.R., Irmak, S., Tarkalson, D., (2006). Yield response of corn to deficit irrigation in a semiarid climate. Agric. Water Manage. 84, 101- 112 .

Penman, H. L. (1950). The dependence of transpiration on weather and soil conditions. Journal of Soil Science, 1(1), 74-89.

Penman, H. L. 1953. The physical bases of irrigation control. Rep. 13 Int. Hort. Cong.

Rhoades, F.M., Bennett, J.M. (1990). Corn. In: Stewart, B.A., Nielsen, D.R. (Eds), Irrigation of Agricultural Crops. Madison, WI, pp.569596.

Robins, J.S., Domingo C.E. (1953). Some effects of severe soil moisture deficits at specific growth stages of corn. Agron. J. 45:618-621.

Soltanbeigi, A. (2019). Effect of drought stress and seed pretreatment with CCC on yield and yield components of maize varieties. Tekirdağ Ziraat Fakültesi Dergisi, 16(1), 61-70.

Süheri, S., Hussein, N. M. H., Kurtar, E. S., Yavuz, N., and Yeşim, D. A. L. (2020). Determination of Yield and Quality of Different Snap Bean Varieties Under Deficit Irrigation. Journal of Tekırdag Agricultural Faculty, 17(2), 252-263.

Stone, L.R., (2003). Crop water use requirements and water use efficiencies. In: Proceedings of the 15th Annual Central Plains Irrigation Conference and Exposition, February 4-5, Colby, Kansas, pp. 127-133.

Zamani, A. S., and Nasseri, A. (2008). Response of dryland wheat production and precipitation water productivity to planting date. Asian Journal of Plant Sciences, 7(3), 323-326.

Zhang, X., Chen, S., Sun, H., Wang, Y., and Shao, L. (2010). Water use efficiency and associated traits in winter wheat cultivars in the North China Plain. Agricultural Water Management, 97(8), 1117-1125. 